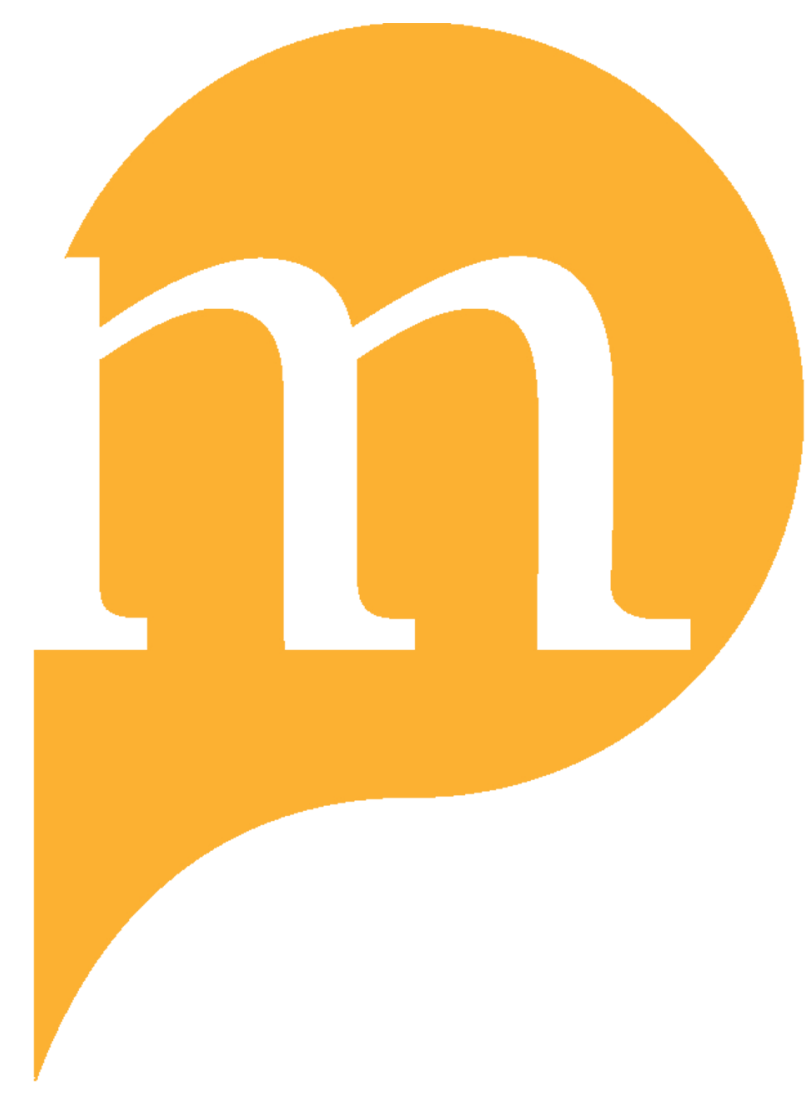

PROJECT MUSE 


\section{Reading Austin Rhetorically}

Andrew Munro

This article reads John L. Austin rhetorically and achieves two things thereby. First, it grasps the tensions subtending Austin's speech-act theory. These tensions arguably stem from Austin's distinct engagements with his brief to consider how saying something is to do something. Second, this article assesses the usefulness of Austin's notion of perlocution to the description of discursive events. I take such description to be a concern of the interpretive humanities in general and of rhetoric in particular. To gauge perlocution's utility, I compare its descriptive purchase with that of illocution, signaling some productive affinities between Austin and the purposive, processual conception of semiosis developed by Charles S. Peirce.

Given John L. Austin's Oxonian pedigree, we should expect his discussion of how "to say something is to do something" (1962, I2) to be taken up analytically. However, Austin also offers resources that have been exploited outside of traditional analytic philosophy — think of certain analytic feminist work, for example, or literary critical uses of performativity. For the most part, such work extends and inflects Austin's notion of illocution and its related concepts of force and performativity for disciplinary-specific ends.

This tendency in reading Austin to focus on illocution and its related concepts is understandable. After all, Austin devotes most of his Harvard lectures, assembled in How to Do Things with Words (1962), to developing an illocutionary inquiry, and the subsequent refinement of speech-act theory within the philosophy of language and linguistics fairly fixates on this topic. However, Austin counterposes illocution, or what we do in saying 
what we say, to perlocution, or what we do by saying what we say. These two tensively related approaches to speech as action entrain distinct conceptions of discursive linking, responsibility, and agency. In what follows, I read these conceptions contrastively to assess the usefulness of Austinian speech-act theory in general and of perlocution in particular for describing discursive events. I hope to show that with perlocution, Austin engages some properly rhetorical lines of inquiry. To make this case, I appeal to the conception of semiosis developed by Charles S. Peirce, whose relevance to the philosophy-rhetoric interface is not lost on this journal. ${ }^{1}$ Two heuristic reasons motivate my appeal. First, Peirce and Austin share some suggestive similarities. Second, the breadth of Peirce's semiotic inquiry-including his prototypical speech-act theory-helps us to counter the tendency to read Austin through an exclusively Searlean lens. ${ }^{2}$ While certain aspects of Peirce's inquiry are indeed germane to the illocutionary project advanced by John Searle, his broader conception of semiosis resonates with Austin's perlocutionary concerns.

Both Peirce and Austin have been framed as disciplinary founding fathers with highly contested legacies. Peirce has been taxed with beginning almost everything but finishing almost nothing; Austin's speech-act project has similarly been portrayed by himself and others as winding up in failure. ${ }^{3}$ If the drawing of distinctions was Austin's "fundamental philosophical interest" (Cavell 1967, 253), the distinctions he drew, or so the tale goes, invariably unraveled. By distinguishing between truth-evaluable constatives and the performative doing of things with words, for example, Austin would challenge the verification procedures of logical positivism. The inadequacies of this distinction, however, would prompt Austin to abandon it in favor of his locution/illocution/perlocution trichotomy. ${ }^{4}$ Prima facie, the structure of Austin's lectures supports this reading. However, underlying these "failings" is a more interesting and fundamental floundering: Austin's inclination is to focus on illocution, but his brief to consider how saying something is to do something compels him to engage the "wider spheres of entanglement, involvement, and transaction" (Colapietro 2007, 36) that are the concern of perlocution or rhetoric.

Austin's attention to the intension of that "very vague" (Austin I962, 9I) expression, "doing something," sees him conceive of his illocutionary project as constitutively related to perlocutionary questions of how utterances are taken up. Such questions concern what Peirce calls the "interpretant." For Peirce, semiosis is a dynamic, purposive process whereby a sign, or representamen, represents an object to another sign, or interpretant. This 
mediating, translational process is infinitely regressive and progressive: the interpretant is in turn a sign, just as the represented object is itself always already a representamen. ${ }^{5} \mathrm{~A}$ sign is thus something that addresses someone: it "stands to somebody for something in some respect or capacity" (I93I- 58 , 2.228). However, although nothing is a sign pragmatically unless it is interpreted as such, there remains a sense in which signs are also describable in futuro. ${ }^{6}$ Hence the ambivalence in Thomas Short's $(1982,308)$ explication of Peirce's uses of the word "meaning," which he glosses as "referring to an effect which the sign is fit to produce or does produce or would eventually produce." Tensions similarly pervade Austinian speech-act theory, in which the presuppositions of illocutionary description are troubled by perlocutionary concerns.

Of all his distinctions, Austin identifies the one between illocution and perlocution as that which is "likeliest to give trouble" (I962, I09). It is also that which best articulates the tensions subtending his linguistic phenomenology, in which a reflection on speech acts as what Searle (1979, ix) calls "natural conceptual kinds" runs up against a consideration of what is presupposed by describing an utterance as unilateral and complete or at an end. The real trouble given by Austin's categories of illocution and perlocution is their generation of different descriptive effects: different consequences ensue from these different delimitings of speech as action-different ways of thinking discursive linking, responsibility, and agency.

Both the primacy that Austin would accord illocution and the persistence with which perlocution worries his project can be read off his explanatory moves. These last include his fixation on the explicit performative; his particular appeals to context; his choice of objects of analysis and analogies; his explanatory use of force; and his restrictive construal of uptake. I address each briefly in turn.

Explicit performative. Austin first appeals to the explicit performativewhich refers to the uttering of an expression commonly used to name an act performing that act-to get his provisional dichotomy of constative/ performative off the ground. He then develops his inquiry by framing the explicit performative as exemplary of illocution. In his illocutionary "turn," Austin retains the "slippery" tests initially proposed for isolating explicit performative verbs; they are now to be used "for sorting out those verbs which make explicit ... the illocutionary force of an utterance" (1962, I49). Like his initial "sly" focus on first-person singular present indicative active verbs or his "devious" linguistic tests, Austin's retention of the explicit performative is not without design $(1962,56, \mathrm{I22})$. An explicit performative verb 
is to "make plain how the action is to be taken or understood" (1962, 70), thereby eliminating any "inferential fuss" (Bach and Harnish 1989, 544). However, the explicit performative ultimately fails in its brief "to obviate disagreements as to the description of illocutionary acts" (Austin I962, II5). Descriptive disagreements persist precisely where the illocutionary impulse is troubled by perlocution. An attempt to dispel this trouble informs Austin's ambivalent appeals to context.

Context. Austin claims to be exercised by praxeological questions of contextualized language use, in which speech acts are described in terms of responsibilities and consequences or effects. ${ }^{7}$ However, although his talk of the "total speech act in the total speech situation" (I962, I47) sounds properly perlocutionary, Austin's appeals to the "total situation in which the utterance is issued" $(1962,52)$ more often subserve illocutionary inquiry. For illocutionary ends, he describes the "circumstances of the utterance" as "over-rich": they "lend themselves to equivocation and inadequate discrimination. . . . [M] oreover," he adds, "we use them for other purposes" (1962, 76). Such purposes are those of perlocution, which exceeds the "ordinary" disciplining constraints of illocution. A normative foreclosure characterizes what Klaus Oehler (1986, 6inio) would call the "domination-free" analytic contexts of illocution, while an indeliminable unsettling characterizes the contexts that press the perlocutionary. Again, an attempt to elide this last determines Austin's choice of objects of illocutionary analysis and analogies.

Objects of analysis and analogies. Austin's examples are many and, at times, varied. His exposition of felicity conditions, for instance, ranges from constraints on baptizing penguins to the appropriateness of appointing a horse as consul. However, if classical training and a wry sense of humor dispose Austin to invoke Caligula or quote Euripedes, we should also note the generic or disciplinary nature of these appeals. Such scenarios are exemplary of illocutionary inquiry - think of Searle's captured American soldier trying to pass as German by reciting some high school Goethe or his stupefied cats on mats and hamburgers encased in solid plastic. ${ }^{8}$ And yet, for all the variety of Austin's examples, two argumentative moves predominate: he repeatedly appeals to instances of promising, or commissives, as well as to legal and paralegal analogies. Let us defer discussion of Austin's predilection for promising to address his use of legal topoi.

For Austin, legal figures embody the illocutionary ideal of conventional, formulaic efficacy. Austin adduces the legal acception of "operative" as analogous to performativity and appeals to his figure of the judge, who 
"should be able to decide, by hearing what was said, what locutionary and illocutionary acts were performed, but not what perlocutionary acts were achieved" (1962, I2I). Plainly, Austin's invocations of law do not foreground the interpretive latitude or indeterminacy of signs used in real forensic activity, which is constrained but also enabled by its own institutional topics and protocols of inquiry. Rather, his focusing on the "conventional procedures" (Austin 1962, I9), what Joseph Raz calls the "special formal and ceremonial acts" by which legal powers are exercised, means that his legal figures endorse a zero degree of interpretive activity (MacCormick and Raz 1972, 8I). ${ }^{9}$ For illocutionary ends, speech acts result from a systematizing suspension of the contingencies of real contexts, genres, and history.

Force. By invoking a distinction between propositional content and illocutionary force, Searle helps to secure our association of Austin's use of force with illocution. ${ }^{10}$ Undoubtedly, in opposing an utterance's meaning to its force, Austin uses force to denote illocutionary type. However, despite the fact that Austin predicates force of illocution, his appeal to how in one sense an utterance is to be taken suffers problems of a sort not associated with Searle. Relating to the extent to which Austin's project opens to perlocution, these problems can be read off the fortunes of statements in his Harvard talks.

For Searle, the nature of statements is straightforward. The notion of illocutionary purpose or point allows him to classify statements as assertives, the illocutionary point of which is "to commit the speaker (in varying degrees) to something's being the case, to the truth of the expressed proposition" (1979, I2). This internal, analytic criterion enables Searle to claim that statements "are not by definition attempts to produce perlocutionary effects" (3). For Austin, however, things are not so clear. In lecture I, an appeal to statements enables him to posit the constative/performative distinction: "Grammarians," he notes, "have regularly pointed out that not all 'sentences' are (used in making) statements” (1962, I). By lecture I2, however, statements have been classified, albeit shakily, under that "difficult to define" (1962, 151) illocutionary class, the expositive. ${ }^{11}$ Interestingly, Austin also stresses in this final lecture that he has "omitted any direct consideration of the illocutionary force of statements" (I962, I48).

Plainly, the force in question here is not as resolutely illocutionary as Searle's. Informed by the sense that saying anything at all "is always doing a good many different things" (I96I, 238), Austin's inquiry cannot quite bracket off the fact that "in stating, we are or may be performing perlocutionary acts of all kinds" (1962, 138). With the acknowledgment that "any, or almost any, perlocutionary act is liable to be brought off, in sufficiently special 
circumstances, by the issuing, with or without calculation, of any utterance whatsoever, and in particular by a straightforward constative utterance" (1962, I09), comes an understanding that talk of the effects of real utterances in real circumstances entrains questions of discursive responsibility. Only for illocutionary purposes might one simply state the facts. Implicit in Austin, this point is made explicitly in Peirce's analysis of assertoric acts.

Like Searle, Peirce draws something like a propositional content/ illocutionary force distinction, primarily in relation to assertions. ${ }^{12}$ Like Searle, too, he reads assertives in terms of a speakerly commitment to a belief in the truth of an assertion's propositional content. ${ }^{13}$ However-and correlativelyPeirce also describes an assertoric act in terms of an other-oriented induction of belief: "When a writer makes an assertion, his principal purpose is to induce the reader to believe in the reality of the fact asserted" (I93I- $-58,4.353$ ); every assertion "involves an effort to make the intended interpreter believe what is asserted" (I93I-58, 5.546). Belief, in turn, is construed in terms of a "deliberate preparedness to act according to the formula believed" (I93I-58, 5.28). Indeed, Peirce compares an assertion with the taking of a binding oath before a magistrate or notary, effectively stressing the assumption of responsibility as a perlocutionary concern: grounded in an occasion, an assertion is a purposive act entraining very real effects. Far from a "purely representitious event," an assertion "involves an act, an exertion of energy, and is liable to real consequences, or effects" (I93I-58, 5.547). ${ }^{14}$ For Peirce, an assertion is "not mere saying, but is doing" (1931-58, 5.546); this doing is addressive, and as such, is constitutively linked to questions of the accidents, urgencies, and responsibilities of real discursive linking. Austin agrees: "The giving of straightforward information produces, almost always, consequential effects upon action" (I962, IIO).

To analyze an assertion, then, Peirce brings together two branches of semeiotic: his speculative grammar and speculative rhetoric. Speculative grammar analyzes the nature of an assertion, deducing its formal constituents. ${ }^{15}$ This kind of reasoning, however, is "only half a method": a proper analysis must turn to the "rhetorical evidence" (Peirce $193 \mathrm{I}^{-58}$, 2.333). Hence the recourse to speculative rhetoric. Formally imperfect, this branch of semeiotic turns on experience, reading signs "in their efficacy and fecundity" (Colapietro 2007, 43). Austin does and does not commit to such a shift from abstract definition to pragmatic clarification. This is evident not just in his use of force but also in his construal of uptake.

Uptake. Austin tries to restrict uptake to the domain of illocution by construing it as the "bringing about [of] the understanding of the meaning and of the force of the locution" (1962, II6). However, uptake is drawn to 
a perlocutionary usage: uptake as upshot, the translation of a sign into a further sign, a semio-rhetorical effect. ${ }^{16}$ Understandably, readings of Austin often treat "uptake" and "perlocution" as quasi synonyms. Dennis Kurzon, for example, advocates using "uptake" to refer to "the effect of the utterance on the hearer"- "even though Austin tried to distinguish between 'uptake' and 'perlocutionary effect"' $(1998,595)$. Judith Butler similarly refers to perlocution when mentioning "the problem of "uptake" (I997, II3). Austin, however, would associate uptake with the devices of illocution and a certain construal of felicity: the happily performed illocutionary act "involves the securing of uptake" (1962, II6). Quentin Skinner is right to claim in this respect that Austin "provided no account of what is involved in successful uptake" (I970, II8) - but within illocution's conventional frame, no further account is required. Within the abstracting, "ordinary" space of illocution, understanding works transparently.

Arguments to the effect that the descriptor "ordinary" denotes nonphilosophical language, that it incites attention to the familiar or that it designates a participatory knowledge are all very well. ${ }^{17}$ What they neglect, however, is how this "ordinary" connotes a series of illocutionary bracketing techniques. Within the "ordinary" space of illocution, Searle rebadges uptake as "illocutionary effect." This effect on the hearer "is not a belief or response"; rather, "it consists simply in the hearer understanding the utterance of the speaker" (1969, 47). As long as certain "circumstances of situation" (Austin 1962, 139) are in order, an utterance is successfully performed the moment its force is recognized. This moment, in turn, is determined simply by such circumstances' being in place: when by illocutionary fiat "normal input and output conditions" (Searle 1969, 57) are deemed to obtain and other things, including interlocutors, are presumed to be equal, uptake is assumed to ensue.

In effect, this restrictive acception of uptake marks the limit of illocution's engagement with questions of discursive commitment and linking. Searle's analyses of promising exemplify this tendency. Rather than discuss his proof for deriving an ought from an is, I note simply that Searle's framing of promising as a linguistic institutional fact entrains particular descriptive effects. Underwritten by the certain conditions and ceteris paribus clauses of the ordinary, this perspective on saying something is less about interlocutors acting in the world than about the nondefective performance of speech acts through the observance of constitutive rules. By sticking to a "simple and idealized case" $(1969,56)$ of promising in which commitments and responsibilities are understood institutionally, Searle avoids the rougher ground of human history. 
At points, Austin similarly treats promising as an object of illocutionary inquiry, as when he notes that to promise "is not to try to do anything" (1962, I25). And yet, at other points, Austin considers promising in more perlocutionary terms, as when he notes that by saying "I promise" "I have bound myself to others, and staked my reputation, in a new way" (I96I, 67). Stanley Cavell reprises this sense of hearer entitlement and speaker responsibility in noting that "the 'pragmatic implications' of our utterances are (or, if we are feeling perverse, or tempted to speak carelessly, or chafing under an effort of honesty, let us say must be) meant, ... they are an essential part of what we mean when we say something, of what it is to mean something. And what we mean (intend) to say, like what we mean (intend) to do, is something we are responsible for" $(1969,32)$.

Like utterances generally, promising is thus also construable as a "social act," at once responsive and oriented toward a response. ${ }^{18}$ More than a vague creation of "expectations in the hearer about the future" (Searle 1969, 46), a promise induces the promisee to rely on-to act in accordance with or in relation to - $\mathrm{a}$ future performance by the promisor. Promises are thus explicable in terms of "an intention to bring about a specific perlocutionary effect" (MacCormick in MacCormick and Raz 1972, 63-64). However, such a description of a promise as a means of eliciting an interpretant response by the promisee or promisees sits uneasily with an illocutionary construal of promissory responsibility, in which a speaker's placing herself under an obligation is understood internally.

2

Moving beyond illocutionary fixity to attend to the consequences and effects of utterances, we find that the perlocutionary analysis of what we do by saying what we say opens to complex accounts of utterance action in which interlocutors are construed as situated and situating hearer-speakers. For perlocutionary purposes, such interpreters are practically implicated persons whose utterances entrain attributions and abrogations of responsibility for discursive rather than merely linguistic or semantico-sentential linkings. The perlocutionary domain is thus one of retrospective description, of "subsequent" descriptions of what someone did with words.

A range of attempts have been made to excise perlocution from speech-act theory. This excision is effected primarily by omission-consider Searle's fixation on illocution. When explicitly considered, however, perlocution is variously framed as exceeding linguistic communication or operating 
within a distinct system. ${ }^{19}$ Lying beyond speech-act theory's declared area of competence, perlocution is at best consigned to a general pragmatics. ${ }^{20}$ If the "consequential reactions of the hearer" are in fact countenanced, they are placed within a "richer context" (Wunderlich 1980, 304) still impelled by the illocutionary: context amounts to cotext with a requirement of copresence, utterances are simple sentential signs, speakers are not hearers, hearers are not speakers, and both are kept to a minimum. ${ }^{21}$ "Ordinary" circumstances are thus presumed to obtain and perlocutionary acts are either deemed an "absurdity" (Burkhardt 1990, 93), considered as solely the "product of a speaker's intention" (Gaines 1979, 215), or framed as a happy transaction, a "joint endeavour" (Gu 1993, 420) in which speaker and hearer adopt an "identical goal" (Gu 1994, I9I). This latter conception is also underwritten by illocution: "perlocutionary effects" and "response-acts" (Gu 1993, 422) are understood exclusively to promote an unspeakerly version of hearer agency. Although conceding that a perlocutionary act is never performed by the speaker alone, this construal of perlocution fails to engage questions of discursive responsibility.

Austinian perlocution, however, works otherwise. Austin both stresses the importance of "the intents and purposes of the utterance and its context" (1962, I42) and admits the unintended within perlocution's ambit. Hence the modalization of his description of the perlocutionary act: saying something "will often, or even normally, produce certain consequential effects upon the feelings, thoughts, or actions of the audience, or of the speaker, or of other persons: and it may be done with the design, intention, or purpose of producing them" (I962, IOI). Indeed, the possibility of unintended effects subtends Austin's talk of acts: "When the speaker intends to produce an effect it may nevertheless not occur, and ... when he does not intend to produce it or intends not to produce it it may nevertheless occur" (1962, 105). The perlocutionary act may thus include "what in a way are consequences, as when we say 'By doing $x \mathrm{I}$ was doing $y$ ': we do bring in a greater or lesser stretch of 'consequences' always, some of which may be 'unintentional"' (I962, I06).

These considerations suggest to Austin the need for a high-level "doctrine about [human] action" (1962, 106). Such a doctrine could be fleshed out by attending to some parallels discernible between Austinian perlocution and Peirce's semeiotic. This would entail a focus on speaker and hearer responsibilities for utterances understood as discursive response. In effect, to consider "saying something" as producing "certain consequential effects upon the feelings, thoughts, or actions of the audience, or of the speaker, or of other persons" (Austin I962, IOI) is to take a semiotic 
turn in which "our cognitive understandings, our sustained actions, and our emotional responses" (Colapietro 1997, 262) are construed in terms of the occasions and situations of discursive events. This rhetorical doctrine holds utterances to be purposive signs of preceding signs; it construes interlocutors as desiring sign users, historically implicated and practically involved, and understands the contexts in which these rhetorical agents act as discursively dialogical rather than as structured by the speaker/hearer dyads and regimes of copresence of the illocutionary "ordinary." Take, for example, a 2006 Ramadan address in the Lakemba mosque, Sydney, by Australia's most senior Muslim cleric, in which he compared immodestly dressed women with uncovered meat. Only a perlocutionary analysis, attending to the outspoken person of Sheikh Taj el-Din al-Hilali, the office he occupied, the occasion and rhetorical situation of his address and those of its translation and reporting, the Sydney gang rapes of 2000, the sectarian violence in Cronulla in 2005, and so forth could begin to account for the interpretants of outrage that al-Hilali's utterance provoked..$^{22}$ For perlocutionary ends, speech is the action of situated and situating agents involved in and contesting the rhetorical translation of signs, and responsibility is ascribed to and abrogated of speakers and hearers for their utterances' intended and unintended interpretive effects.

To talk of utterances for illocutionary ends is to pursue an abstracting classificatory project-consider Searle's identification with a Saussurean construal of langue and his tidying up of Austin's categories. ${ }^{23}$ Perlocutionary description, by contrast, attends to the unsystematizable, tracing the lives of signs in terms of their histories of use. From this perspective, a perlocutionary act - the achievement in practice of determinate effects by saying something-entrains ascriptions, assumptions, and abrogations of speaker and hearer responsibilities.

Austin approaches the urgencies and responsibilities of real discursive linking when he identifies the "total speech act in the total speech situation" as "the only actual phenomenon" he is "engaged in elucidating" (1962, I47). With perlocution pushing to describe utterance signs in actu, doubts about the status of statements unheard or warnings issued sotto voce become impertinent, echoing that "ferocious metaphysical dispute" over whether a person ever "goes round" (James 1956, 198) an evasive squirrel clinging to a tree.

That said, signs are, as I have noted, describable in futuro. In a sense, this is the business of illocution understood capaciously. Peirce provides some purchase for broadly illocutionary construals of speech as communicative action - witness his intentional, effectual and communicational interpretant 
trichotomy in which the intentional interpretant, as "a determination of the mind of the utterer," and the effectual interpretant, as "a determination of the mind of the interpreter," are geared to the communicational interpretant, "a determination of that mind into which the minds of utterer and interpreter have to be fused in order that any communication should take place" (Peirce qtd. in Hardwick 1977, 196). ${ }^{24}$ Peirce calls the mind determined by the communicational interpretant the "commens," which "consists of all that is, and must be, well understood between utterer and interpreter at the outset, in order that the sign in question should fulfill its function" (Peirce qtd. in Hardwick 1977, I96). A particular construal of common ground or collateral experience is critical to such framings of communication; so too is a notion of semiosis in which the mediating sign effaces itself, acting upon the interpreting mind "as if the object itself had acted upon it" (Peirce 1998, 39r). ${ }^{25}$ To the extent that it focuses on definition and classification rather than effective sign use, to the extent that it would determine "the general conditions of signs being signs" (Peirce I931-58, I.444), idealizing illocution aligns with the speculative grammatical branch of Peirce's semeiotic.

Although aspects of Peirce's work are germane to illocutionary description, the purposive, processual nature of his semeiotic ensures Peirce's usefulness to perlocutionary inquiry. Perlocution attends to signs in futuro in relation to signs in actu, to contingent utterances taken up within what Valentin Volosinov $(1973,38)$ calls the "whole pragmatic run of life." As such, perlocutionary inquiry is alert to interpretant and interpreter multiplicity, to different uptakes effected by rhetorical agents with diverse pasts and disjunctive present purposes. Perlocution's attention to an utterance's "consequential effects" (Austin 1962, IOI) recalls Peirce's dynamic interpretant, which "consists in [the] direct effect actually produced by a Sign upon an Interpreter of it." Experienced in each act of interpretation, the dynamic interpretant comprises "an effect ... of the Sign upon an individual mind ... or upon a number of actual individual minds by independent action upon each" (Peirce qtd. in Hardwick 1977, IIO-II). Only the dynamic interpretant deals in existents and situational specificity: only the dynamic interpretant is a "single actual event" (Peirce qtd. in Hardwick I977, III) having "the concreteness of actuality" (Short I986, II5).

To assimilate a perlocutionary focus on the real effects of utterances to the dynamic interpretant is to construe utterances as linked to by other utterers: it is to attend to interpretants in relation to interpreters who comprise a "bundle of habits, interpreting many things at once, and from various perspectives" (Lyne 1980, I67). Shifting from semantico-sentential 
abstractions, a perlocutionary inquiry locates an utterance sign's meaning and responsibilities in relation to its simple or complex response.

Although not technically defined, "meaning" is often used by Peirce in this sense: the meaning of an act in practice is its range of upshots or uptakes. This pragmatic acception of the word "meaning" resonates with what Peirce calls "speculative rhetoric." Fragmentarily developed, this "highest and most living branch" (Peirce I93I-58, 2.332) of semeiotic has occasioned much debate. If one reads it for its rhetorico-discursive import, however, speculative rhetoric's concern for the production of interpretants aligns with a broadly perlocutionary approach to utterance action and meaning. ${ }^{26}$

Perlocutionary description participates in speculative rhetoric's concern for the "general conditions of the reference of symbols and other signs to the interpretants which they aim to determine" (Peirce I93I-58, 2.93). Note that to examine the "formal conditions of the force of symbols" (193I-58, I.559) from this perspective is in fact to attend to semio-rhetorical particulars: to describe how one sign gives birth to another is to attend to interpretant signs in esse, to real uptakes and their contingencies.

We can thus posit some broad affinities, if not broadly parallel trajectories, for Austin and Peirce. Just as an attention to the conditions of reference of signs in relation to their interpretants supersedes a semantic account of meaning in Peirce, just as he moves from "the level of abstract definition to that of pragmatic clarification" (Colapietro 2007, I9), from speculative grammar to speculative rhetoric, so too does an attention to speech as action and meaning in Austin oscillate between an illocutionary focus and perlocutionary questions of interpretive effects. ${ }^{27} \mathrm{Just}$ as speculative rhetoric opens to wider spheres of entanglement and transaction than those of speculative grammar, so too does perlocution exceed illocution. Just as speculative rhetoric would turn to "concrete, contextual characterizations of semiosis" suggesting the "human face of deliberative agency," so too would perlocution understand speech as action by referring to the "historical practices of situated agents" (Colapietro 2007, 36, 19).

\section{3}

Plainly, the interpretant effects to which a perlocutionary account of meaning attends are open to what Vincent Colapietro $(1995,46)$ calls "the vicissitudes of time, the twists of history." And yet to note that meanings "exceed the boundaries in which they first emerged and the functions for which they were originally ordained" (Colapietro 2004, 229) is not to foreclose talk of 
discursive responsibility. If the speaker's situation as "always already involved in some form of dialogue" precludes the establishment of absolute communicative termini a quo and ad quem in theory, nevertheless, "in practice... more or less definite points of departure can be established" and "resolutions [can] be reached" (Colapietro 1995, 43) in relation to speakers as responsive and responsible or answering and answerable rhetorical agents. Utterances thus read as interpreters' attempts to secure further interpretants in response to perceived situational demands; by interpreting a sign in some respect or capacity, an utterance maintains or reconstrues contextual strictures, linking to the same or other discursive genres or spheres of activity. On 30 September 1938, for example, from the steps of ro Downing Street, London, one British prime minister echoed another, professing to have secured "peace for our time." Chamberlain's declaration may or may not have forced comparisons of himself with Disraeli and may or may not have helped British citizens to sleep quietly that night; what is certain, in any case, is that Hitler's uptake moved from the genre of polite political pacts to another sphere of activity, thereby consigning Chamberlain's assurances to the dustbin of historical irony.

The question of "what we should say when, what words we should use in what situations" (Austin I96I, I30) thus invites reading for its perlocutionary import. By construing utterances as answering speech actions taken up by equally, albeit often differently motivated responses, this question asks which words might be used in which discursive situations with a view to determining particular interpretant effects. Just how a sign determines a response is best understood as its delimiting, rather than overdetermining, a range of possible interpretants. ${ }^{28}$ This delimiting occurs within a conception of semiosis as teleological interpretive activity. Nothing is a sign except in relation to a possible interpretive goal, and interpretive goals are inferred in relation to interpreters' situations, backgrounds, and histories. ${ }^{29}$ Not only does purposiveness distinguish semiosis from "mere dynamical action" (Bergman 2000, 239); it also opens to a perlocutionary evaluation of responsive responsibilities, to the discursive question of the extent to which an agent's performed act is attached to or detached from its products. From a perlocutionary perspective, "one and the same thing," as Short ( 1986, Io6) notes, "may be many different signs at once." Hence, for example, the argument by Clare Montgomery QC, who appeared at the Belmarsh Magistrates' Court, London, to secure the extradition of Wikileaks' head, Julian Assange. Montgomery's assertions are variously heard as primarily legal advocacy (standing for prosecution lawyer Claes Borgström and for the Swedish public prosecutor, Marianne Ny, who issued a European arrest 
warrant for Assange on 7 December 20I0, Montgomery takes her place in a line of interpretants representing Anna Ardin and Sofia Wilén, the alleged sexual assault and rape victims) or primarily a play in the Cablegate saga (a further link in a chain of politically motivated utterances by means of which aggrieved Western governments would terminate Wikileaks' publishing activities).$^{30}$ Real, living utterances are issued and received by different sign users responding differently to differently apprehended situational exigences. No sign is completely determinate, if for no other reason than that no interpreter's interpretation is based on exactly the same experience as that of any other. ${ }^{31}$

Given that the purposefulness of sign action is "rooted in the interpreter, not in signs or their objects" (Short 2007, I7I), and given the diversity of interpreters, the saying of anything at all is almost certainly the doing of a good many different things that result in discursive responsibility being attributed to speakers as well as in speakers being absolved of it. This responsibility exceeds such broadly illocutionary concerns as Searlean sincerity conditions or a Gricean maxim of quality: it exceeds a "linguistic responsibility" (Davis I994, I5) turning on an "ordinary" insistence that we-we-must mean what we say. For the purposes of perlocutionary inquiry, actions are individuated and responsibilities attributed in relation to utterances understood as discursive effects that in turn occasion, or are translated into, further discursive effects. Such responsibility exceeds, for example, the defeasibility mechanisms of conversational implicatures: the retroactive addition of premises to cancel an inductive inference is only always possible within the "ordinary" space and "ordinarily" reparable time of the maximally effective informational exchanges that comprise conversation in logicizing theory. ${ }^{32}$

Nor is discursive responsibility adequately described in terms of, for example, the formalized mechanics and accountabilities of turn taking. ${ }^{33}$ While a conversation-analytic focus might seem to exceed illocutionary inquiry, its adjacency pairs are in fact analogous to what Austin (1962, II6) identifies as those "many illocutionary acts" that "invite by convention a response." To note that a bet requires an acceptance by a taker (1962, 9), for example, is perhaps to note a precondition of illocutionary felicity, but it is not to describe the discursive import of a particular wager, such as that accepted by John Powell, for instance. On 25 September 2010, he took a $\$ 5.00$ partygame bet to receive a punch from a woman; she delivered the punch, and within minutes he died. The illocutionary success of this wager is overshadowed by its perlocutionary import: the wager is translated to the genre of the tribunal, and argument about a series of legal and extralegal issues ensues. ${ }^{34}$ 
Similarly, to describe the purpose of asking a question as being to elicit an answer is to study dialogue as "merely a compositional form in the structuring of speech" (Bakhtin I98I, 279). Plainly, a question is understandable as a "rational contrivance or device" intended to "stimulate the hearer to make a response" (Peirce 1931-58, 3.515, 4.57). However, to understand a question rhetorically, a perlocutionary inquiry considers its orientation toward the response of the other in terms of the "pressing want" or contingent "circumstances of need" that "prompted the contrivance" (Peirce 193I-58, 3.515) to begin with.

By considering actual utterance signs in relation to their interpretant effects, perlocutionary description foregrounds the question of discursive responsibility. One end point in this regard is the nominally "first" speaker answerable for her utterance: in responding to a discursive object, her utterance successfully elicits a desired response. Here, an interpretant uptake is dialogically determined by, and thereby in a responsibilizing sense attributable to, the speech action of the speaker. In practice, such determinate uptakes often exceed the presumptions of cooperation and common purpose informing Gricean complex speaker meaning or an illocutionary postulate of interlocutorial parity. ${ }^{35}$ Another end point is the "first" speaker whose utterance is voided of rhetorical effect. This occurs when a "second" speaker's interpretant links cooptively, translating the "first" speaker's utterance into genres, spheres, interpretive communities and histories in which the "first" speaker had perhaps not participated or would resist being involved. The locus of responsibility herein shifts to the "second" responding speaker, whose interpretant addresses other interlocutors, interpretive routes, or trajectories. The intentions and intentionalities of hearing speakers and speaking hearers are thus not so much produced by rhetorical situations as inferred or ascribed in relation to them.

The perlocutionary description of discursive uptake similarly practices and is subject to evaluations of responsive responsibility. Like the utterances it analyzes, perlocutionary description is implicated in ramified and ramifying interpretive chains. Its engagements with the issue of responsive responsibility emerge from its understanding of utterance uptake as the purposive action of embodied, desiring agents in the world. Perlocutionary description takes the actions of the nominally "first" speaker in any discursive string as always already a response; it considers these discursive strings as tangled and tied to other discursive strings and construes itself in the same binding or situated and situating terms. In place of an illocutionary isolation, perlocutionary description entrains an engagement with the political, ethico-rhetorical question of discursive responsibility. 
To describe utterances as constituents of discursive events is to assume the hermeneutic responsibilities that the partisan, rhetorical work of representation entrains. Faced with the necessity and impossibility of describing the particularities of utterances as singular events, perlocutionary description structures its response toward future uptakes. In so doing, it contributes to the ongoing, contested formation of cultural memory. As something by knowing which we might come to know something more, perlocutionary description attends to and constitutes speech as action in terms of the answering and answerable utterances comprising discursive events.

I have argued that Peirce helps us to read Austin rhetorically and that such a reading shows how different descriptive apparatuses occasion different effects: to describe speech as action in terms of illocution and perlocution is to represent two rather distinct objects.

\section{School of Languages and Linguistics Griffith University Queensland, Australia}

\section{NOTES}

I. Philosophy and Rhetoric has published work by Peirce, in addition to work on his speculative rhetoric. See Braun 1981, Kevelson 1984, and Peirce 1978.

2. Readings of Peirce as a precursor of speech-act theory tend to focus on illocution. See, for instance, Brock 1981a, I98rb, and Martens I98r. For some more rhetorical attempts to join Peirce and Austin, see Lyne I980 and Lyne I98I.

3. See Hacking 1983, 6r. Anne Freadman $(2008,7)$ notes that Hacking's joke bears on both the fragmentary nature of Peirce's work and his place, or lack thereof, in the philosophical canon. Similar claims can be made about Austin, whom Michael Dummett (1994) would relegate to a footnote in the history of analytic philosophy.

4. For versions of this tale, see Dasenbrock 1987, Graham 1977, and Tsu 1998.

5. The object of representation, notes Peirce, "can be nothing but a representation of which the first representation is the interpretant" (I93I-58, I.339). For semiosis as the translation of signs into other signs, see Peirce $1933^{-} 58$, 4.I27, 5.594. See also Freadman 2004. I do not pursue the topic of the final logical interpretant here.

6. For Peirce on signs in actu, see $193 \mathrm{I}^{-}-58,2.308,5.569$. For Peirce on signs in futuro, where there is no requirement that the interpretant in fact exist, see Peirce I93I-58, 2.92, 2.275.

7. See Austin I962, I4, 26, IOI-2.

8. For Austin's penguin and horse examples, see I962, 24, and I961, 225, respectively. For his citation of Euripedes, see 1962, 9-10. For Searle's American soldier example, see 1965, 229, and 1969, 44. For his cats on mats and hamburgers, see 1979, I20-28. 
9. For the performative force of "operative" in law, see Austin I961, 223, and I962, 7; for contractual analogies, see Austin I961, 135-36; for the "special precautions taken in law" to avoid interpretive infelicity, see Austin 1962, 22; for the formulaic, explicit performativity of bequeathing in law, see Austin 1962,33,36; for the performative force of "hereby" in law, see Austin 1962, 57, 6r; for some legal verdictives, see Austin 1962, 88. See also Hillis Miller 200I, Kurzon 1986, and Kurzon 1998. Legal topoi are at the inception of theorizations of speech as action. On Adolf Reinach's early systematic theorization of performative language use with a focus on legal phenomena, see Smith 1990 and Smith 2003. For paradigmatic legal analogies in Peirce's prototypical speech-act analysis of assertoric acts, see Peirce $1933^{-}-58,5.546$, 2.315, 5.30.

Io. See, for instance, Searle 1965, 226, Searle 1968, 420, and Searle 1969, 30.

II. See Austin 1962, I6r. Austin also notes, for example, that stating what our feelings are has "obvious connexions" with that other troublesome category, the behabitive (1962, 159).

I2. See Brock I981a, 320-23, Brock I98Ib, 281, Hilpinen 1998, I52, Pietarinen 2004, 296, and Short 2007, 242ff. The "essential logical properties of propositions," notes Pierre Thibaud "depend upon their use in an assertive situation" (I997, 275). Propositional content is thus not self-sufficient: it "needs to be inscribed within an interpretive chain which sets it ... within the horizon of a communication" (Thibaud $1997,272-73$ ). The "pure proposition" would thus be a most problematic one. See Peirce I93I-58, 2.546.

13. See Peirce 193I-58, 2.335.

I4. While Peirce here characterizes a "judgment," this passage signals the closely analogous relation between judgments and assertions. An assertion, notes Peirce (I93- -58 , 2.252), is an act "intended to affect others, while the judgment is only intended to affect oneself." For belief as consisting in "the deliberate acceptance of a proposition as a basis for conduct," see Peirce 193I-58, 8.337; for analogies between assertions and binding oaths, see Peirce I93I-58, 2.315, 5.30, 5.546.

I5. See Peirce I93I-58, 3.432, 2.333.

I6. For a gloss of Austinian uptake in terms of illocutionary convention, see Strawson 1964. For a construal of uptake in terms of Peircean semiosis, see Freadman 2002.

I7. See Urmson 1967, 235, Fleming 2007, 212, and Hanfling 2000, 54, respectively.

18. On Reinach's “social acts," see Crosby I990.

19. See Bach and Harnish 1989 and Gaines 1979, respectively.

20. See Fish 1976 and Leech 1983 , respectively.

21. For the sign's functioning in the absence of the original sender, receiver, and context of production, see Derrida 1977 and Derrida 1988. Searle's (1977) attempt to foreclose iterability by stressing the logical anteriority of the literal misses how Derridean pragrammatology aligns with Austin's call for a "general doctrine of action."

22. See, for instance, Attard 2007 and Kerbaj 2006.

23. See Searle I969, I7, and Searle I979, I-30, respectively.

24. On speech as communicative action, see, for instance, Apel r98r and Apel r983. 
25. See also Parmentier 1985, 45, and Bergman 2000 for a critique of this last. On "collateral experience" or "common ground," see Peirce I93I-58, 8.178, 2.536, 3.62I. See also Bergman 2000, 24I, Hilpinen I998, I57, Pietarinen 2004, 309, and Thibaud I997, 28I.

26. On speculative rhetoric, see Peirce I93I-58, I.444, I.559, 2.93, 2.229, 4.II6, and Peirce I998, 326. For readings of speculative rhetoric suggesting its rhetorico-discursive import, see Bergman 2000, Bergman 2004, Bergman 2009, Colapietro 2007, and Freadman 2004.

27. See Pietarinen 2004.

28. See Peirce I93I-58, 6.625, 8.I77. See also Liszka 1996, 22-23, Short I98I, 22I, Short 1982, 290, and Short 1986, 105.

29. See Short 198r and Short 1986.

30. See, for instance, Bannerman 20I0, Gentleman 20I0, McSmith 20II, and West and Whyte 2010.

3I. See Peirce I93I-58, 5.506.

32. For Grice's restrictive definition of conversation and his maxim of quality, see Grice I989, 26-28.

33. See, for instance, Sacks, Schegloff, and Jefferson 1974.

34. Illinois woman Tiffany Startz faced charges in relation to the death of John Powell, of which she was acquitted. See Schmadeke 2011.

35. See Kasher 1977, McHoul I994, Pratt 1986, and Sampson 1982.

\section{WORKS CITED}

Apel, Karl-Otto. 1981. Charles S. Peirce From Pragmatism to Pragmaticism. Amherst: University of Massachusetts Press.

- I983. "C. S. Peirce and Post-Tarskian Truth." In The Relevance of Charles Peirce, ed. E. Freeman, 189-223. La Salle, IL: Hegeler Institute.

Attard, Monica. 2007. "Sheikh Taj el-Din al-Hilali, Australia's Most Senior Muslim Cleric, Never Far from the Headlines." ABC Radio National Sunday Profile, II Mar. http://www.abc.net.au/sundayprofile/stories/si868267.htm.

Austin, John L. I96r. Philosophical Papers. Oxford: Oxford University Press. . I962. How to Do Things with Words. Oxford: Oxford University Press.

Bach, Kent, and Robert M. Harnish. I989. "How Performatives Really Work: A Reply to Searle." In Pragmatics Critical Concepts, ed. Asa Kasher, 54I-57. London: Routledge.

Bakhtin, Mikhail M. 198r. The Dialogic Imagination. Trans. Caryl Emerson and Michael Holquist. Austin: University of Texas Press.

Bannerman, Lucy. 2010. "Sex Claim Women in Julian Assange Case Say This Is Nothing to Do with the Pentagon." Australian (Sydney), 8 Dec. http://www.theaustralian.com.au/news/world/sex-claim-women-in-julian-assange-case-say-this-isnothing-to-do-with-the-pentagon/story-e6frg6so-I225967447I42.

Bergman, Mats. 2000. "Reflections on the Role of the Communicative Sign in Semeiotic." Transactions of the Charles S. Peirce Society 36 (2): 225-54. 
- 2004. "The Secret of Rendering Signs Effective: The Import of C. S.Peirce's Semiotic Rhetoric." Paper presented at the 8th Congress of IASS-AIS, Lyon, France.

- 2009. Peirce's Philosophy of Communication. London: Continuum.

Braun, John E. 198I. “The 'Speculative Rhetoric' of Charles Sanders Peirce.” Philosophy and Rhetoric I4 (I): I-I5.

Brock, Jarrett E. r98ra. “An Introduction to Peirce's Theory of Speech Acts.” Transactions of the Charles S. Peirce Society I7 (4): 319-26.

- 1981b. "Peirce and Searle on Assertion."In Proceedings of the C. S. Peirce Bicentennial Congress, Graduate Studies, Texas Tech University, ed. Kenneth L. Ketner, Joseph M. Randsell, Carolyn Eisele, Max H. Fisch, and Charles S. Hardwick, 28I-87. Lubbock: Texas Tech Press.

Burkhardt, Armin. 1990. "Speech Act Theory-The Decline of a Paradigm." In Speech Acts, Meaning, and Intentions. Ed. Armin Burkhardt, 9I-I28. Berlin: Walter de Gruyter.

Butler, Judith. 1997. Excitable Speech: A Politics of the Performative. New York: Routledge.

Cavell, Stanley. 1967. “Austin at Criticism." In The Linguistic Turn, ed. Richard Rorty, 250-60. Chicago: University of Chicago Press.

- 1969. Must We Mean What We Say? Cambridge, MA: Cambridge University Press. Colapietro, Vincent Michael. 1995. "Immediacy, Opposition, and Mediation: Peirce on Irreducible Aspects of the Communicative Process." In Recovering Pragmatism's Voice, ed. Lenore Langsdorf and Andrew R. Smith, 23-48. Albany: State University of New York Press.

- 1997. "The Dynamical Object and the Deliberative Subject." In The Rule of Reason: The Philosophy of Charles Sanders Peirce, ed. Jaqueline Brunning and Paul Foster, 262-88. Toronto: University of Toronto Press.

- 2004. "Signs and Their Vicissitudes: Meanings in Excess of Consciousness and Functionality." Semiotica $\mathrm{I} 48$ (I-4): 229-43.

- 2007. "C. S. Peirce's Rhetorical Turn." Transactions of the Charles S. Peirce Society 43 (I): 16-52.

Crosby, John F. 1990. "Speech Act Theory and Phenomenology." In Speech Acts, Meaning, and Intentions: Critical Approaches to the Philosophy of John R. Searle, ed. Armin Burkhardt, 62-90. Berlin: Walter de Gruyter.

Dasenbrock, Reed Way. 1987. "J. L. Austin and the Articulation of a New Rhetoric." College Composition and Communication 38 (3): 29I-305.

Davis, Steven. 1994. “Anti-Individualism, Responsibility, Deference, and Dissembling." In Pretending to Communicate, ed. Herman Parret, 3-16. Berlin: Walter de Gruyter.

Derrida, Jacques. 1977. “Signature Event Context.” Glyph r: I72-97.

- 1988. Limited Inc. Evanston, IL: Northwestern University Press.

Dummett, Michael. 1994. Origins of Analytical Philosophy. Cambridge, MA: Harvard University Press.

Fish, Stanley. 1976. "How to Do Things with Austin and Searle: Speech Act Theory and Literary Criticism." MLN 9I (4-5): 983-IO25.

Fleming, Richard. 2007. "Review: Rhetorical Investigations and Ordinary Language Criticism." Philosophy and Literature 3I (I): 209-I3.

Freadman, Anne. 2002. "Uptake." In The Rhetoric and Ideology of Genre, ed. Richard M. Coe, Lorelei Lingard, and Tatiana Teslenko, 39-56. Cresskill, NJ: Hampton Press.

- 2004. The Machinery of Talk: Charles Peirce and the Sign Hypothesis. Stanford, CA: Stanford University Press. 
- 2008. "Does 'Peirce' Have a History? A Contribution to a History of the 'Moment of Theory." Culture, Theory, and Critique 49 (I): I-20.

Gaines, Robert N. 1979. "Doing by Saying: Toward a Theory of Perlocution." Quarterly Journal of Speech 65 (2): 207-I7.

Gentleman, Amelia. 20I0. "Julian Assange Rape Allegations: Treatment of Women 'Unfair and Absurd." Guardian (Manchester, UK), 8 Dec. http://www.guardian.co.uk/ media/20Io/dec/o8/julian-assange-rape-allegations.

Graham, Keith. 1977. J. L. Austin A Critique of Ordinary Language Philosophy. Sussex, UK: Harvester Press.

Grice, Herbert Paul. I989. Studies in the Way of Words. Cambridge, MA: Harvard University Press.

Gu, Yueguo. 1993. "The Impasse of Perlocution." Journal of Pragmatics 20 (5): 405-32.

- 1994. "Pragmatics and Rhetorics: A Collaborative Approach to Conversation." In

Pretending to Communicate, ed. Herman Parret, 173-95. Berlin: Walter de Gruyter.

Hacking, Ian. 1983. Representing and Intervening. Cambridge: Cambridge University Press. Hanfling, Oswald. 200o. Philosophy and Ordinary Language. London: Routledge.

Hardwick, Charles S., ed. 1977. Semiotic and Significs: The Correspondence Between Charles S. Peirce and Victoria Lady Welby. Bloomington: Indiana University Press.

Hillis Miller,Joseph. 20or. Speech Acts in Literature. Stanford, CA: Stanford University Press. Hilpinen, Risto. 1998. "Pragmatics and Pragmatism: On C. S. Peirce's Pragmatic Theory of Meaning."In The Role of Pragmatics in Contemporary Philosophy, ed.PaulWeingartner, Gerhard Schurz and Georg Dorn, 151-64. Vienna: Holder-Pichler-Tempsky.

James, William. 1956. Selected Papers on Philosophy. London: J. M. Dent.

Kasher, Asa. 1977. "What Is a Theory of Use?" Journal of Pragmatics I (2): 105-20.

Kerbaj, Richard. 2006. "Muslim Leader Blames Women for Sex Attacks." Australian

(Sydney), 26 Oct. http://www.theaustralian.com.au/news/nation/muslim-leaderblames-women-for-sex-attacks/story-e6frg6nf-inimi24I9II4.

Kevelson, Roberta. 1984. “C. S. Peirce's Speculative Rhetoric.” Philosophy and Rhetoric I7 (I): I6-29.

Kurzon, Dennis. 1986. It is Hereby Performed. . . : Explorations in Legal Speech Acts. Amsterdam: John Benjamins.

- 1998. "The Speech Act Status of Incitement: Perlocutionary Acts Revisited." Journal of Pragmatics 29 (5): 571-96.

Leech, Geoffrey. 1983. Principles of Pragmatics. London: Longman.

Liszka, James Jakob. 1996. A General Introduction to the Semiotic of Charles Sanders Peirce. Bloomington: Indiana University Press.

Lyne, John R. 1980. "Rhetoric and Semiotic in C. S. Peirce.” Quarterly Journal of Speech 66 (2): $155-68$.

- I98I. "Speech Acts in a Semiotic Frame." Communication Quarterly 29 (3): 202-08. MacCormick, Neil, and Joseph Raz. 1972. "Voluntary Obligations and Normative Powers." Proceedings of the Aristotelian Society supp. 46: 59-I02.

Martens, Ekkehard. 198r. "C. S. Peirce on Speech Acts." Proceedings of the C. S. Peirce Bicentennial International Congress, Graduate Studies, Texas Tech University, ed. Kenneth L. Ketner, Joseph M. Randsell, Carolyn Eisele, Max H. Fisch, and Charles S. Hardwick, 289-92. Lubbock: Texas Tech Press.

McHoul, Alec. 1994. “Con/versation." In Pretending to Communicate, ed. Herman Parret, I96-2II. Berlin: Walter de Gruyter. 
McSmith, Andy. 20Ir. "Julian Assange Accused of 'Roughing Up' Alleged Sexual-Assault Victim." Independent (London), I4 Jul. http://www.independent.co.uk/news/ uk/crime/julian-assange-accused-of-roughing-up-alleged-sexualassaultvictim-231330r.html.

Oehler, Klaus. 1986. "Is a Transcendental Foundation of Semiotics Possible? A Peircean Consideration." Transactions of the Charles S. Peirce Society 23 (I): 45-63.

Parmentier, Richard J. 1985. "Signs' Place in Medias Res: Peirce's Concept of Semiotic Mediation." In Semiotic Mediation: Sociocultural and Psychological Perspectives, ed. Elizabeth Mertz and Richard. J. Parmentier, 23-48. Orlando, FL: Academic Press.

Peirce, Charles Sanders. 1931-58. Collected Papers of Charles Sanders Peirce. Cambridge, MA: Harvard University Press.

- I978. "Ideas, Stray or Stolen, about Scientific Writing." Philosophy and Rhetoric II (3): I47-55.

- 1998. The Essential Peirce: Selected Philosophical Writings. Vol. 2. Bloomington: Indiana University Press.

Pietarinen, Ahti-Veikko. 2004. "Grice in the Wake of Peirce." Pragmatics and Cognition I2 (2): 295-315.

Pratt, Mary Louise. 1986. "Ideology and Speech-Act Theory." Poetics Today 7 (I): 59-72.

Sacks, Harvey, Emanuel A. Schegloff, and Gail Jefferson. 1974. "A Simplest Systematics for the Organization of Turn-Taking for Conversation." Language 50 (4): 696-735.

Sampson, Geoffrey. 1982. "The Economics of Conversation." In Mutual Knowledge, ed. Neilson V. Smith, 200-210. London: Academic Press.

Schmadeke, Steve. 20Ir. "Trial Begins for Woman Who Threw Fatal Punch at a Party." Chicago Tribune, ${ }_{3}$ Oct. http://www.chicagotribune.com/news/local/ct-met-onepunch-fatal-1004-20III004,0,49078r.story.

Searle, John R. 1965. "What Is a Speech Act?” In Philosophy in America, ed. Max Black, 22I-39. Ithaca, NY: Cornell University Press.

- I968. "Austin on Locutionary and Illocutionary Acts." Philosophical Review 77 (4): 405-24.

- 1969. Speech Acts: An Essay in the Philosophy of Language. Cambridge: Cambridge University Press.

- 1977. "Reiterating the Differences: A Reply to Derrida." Glyph r: 198-208.

- 1979. Expression and Meaning Studies in the Theory of Speech Acts. Cambridge: Cambridge University Press.

Short, Thomas L. 1981. "Semeiosis and Intentionality." Transactions of the Charles S. Peirce Society I7 (3): 197-223.

- 1982. "Life Among the Legisigns." Transactions of the Charles S. Peirce Society I8 (4): 285-310.

1986. "What They Said in Amsterdam: Peirce's Semiotic Today." Semiotica 60 (I-2): 103-28.

- 2007. Peirce's Theory of Signs. New York: Cambridge University Press.

Skinner, Quentin. 1970. "Conventions and the Understanding of Speech Acts." Philosophical Quarterly 20 (79): II8-38.

Smith, Barry. 1990. "Towards a History of Speech Act Theory." In Speech Acts, Meaning, and Intentions: Critical Approaches to the Philosophy of John R. Searle. Ed. Armin Burkhardt, 29-6r. Berlin: Walter de Gruyter. 
—_. 2003. "John Searle: From Speech Acts to Social Reality." In John Searle, ed. Barry Smith, I-34. London: Cambridge University Press.

Strawson, Peter F. 1964. "Intention and Convention in Speech Acts." Philosophical Review $73(4): 439-60$.

Thibaud,Pierre. 1997."Between Saying and Doing: Peirce's Propositional Space." Transactions of the Charles S. Peirce Society 33 (2): 270-327.

Tsu, Jing. I998. "Pleasure in Failure: The Guilty Subject in Nietzsche, Heidegger, and Austin." SubStance 27 (I): 89-I04.

Urmson, James O. 1967. “J. L. Austin.” In The Linguistic Turn, ed. Richard Rorty, 232-38. Chicago: University of Chicago Press.

Volosinov, Valentin. 1973. Marxism and the Philosophy of Language. New York: Seminar Press.

West, Andrew, and Sarah Whyte. 20I0. "Victims, Jilted Lovers, or Undercover Agents." Sydney (Australia) Morning Herald, ig Dec. http://www.smh.com.au/technology/ technology-news/victims-jilted-lovers-or-undercover-agents-20Iог2I8-igrae.html.

Wunderlich, Dieter. 1980. "Methodological Remarks on Speech Act Theory." In Speech Act Theory and Pragmatics, ed. John R. Searle, Ferenc Kiefer, and Manfred Bierwisch, 29I-3I2. Dordrecht: Reidel. 